\title{
ANALISIS PROGRAM PEMBERDAYAAN MASYARAKAT PADA USAHA MENENGAH KECIL DAN MIKRO (UMKM) \\ (Studi di UMKM Pengrajin Batik Kampoeng Jetis dan Pengrajin Koperasi Intako Tanggulangin Sidoarjo)
}

\section{Ertien Rining Nawangsari}

UPN “Veteran” Jawa Timur, ertien.riningnawangsari@yahoo.com

\begin{abstract}
Abstrak
Sidoarjo merupakan kota UMKM yang memiliki jumlah industri yang cukup banyak, salah satunya adalah industri kecil pengrajin batik yang terletak di Kampung Batik Jetis dan Pengrajin Koperasi Intako Tanggulangin Sidoarjo. Perkembangan UMKN di kedua tempat masih perlu mendapat perhatian, Sehingga menarik untuk di analisis bagaimana program pemberdayaan yang mendukung pengembangan UMKM pengrajin batik dan pengrajin Intako di kota Sidoarjo? Dan apa saja yang menjadi faktor penghambat dan pendukung di dalam UMKM Pengrajin Batik dan UMKM Intako? Penelitian ini adalah penelitian dengan pendekatan diskriptif kualitatif. Umtuk mendiskripsikan dan menganalisis tentang Upaya pemberdayaan dengan yang dilakukan oleh Dinas Koperasi, UKM, Perindustrian, Perdagangan dan ESDM Kabupaten Sidoarjo dengan berbagai upaya (1) Fasilitasi permodalan, (2) Dukungan kemudahan memperoleh bahan baku dan fasilitas pendukung dalam proses produksi, (3) Pendidikan dan pelatihan untuk meningkatkan kemampuan manajerial dan produksi serta lain-lain jenis pendidikan dan pelatihan yang dapat mendukung pemberdayaan Usaha Mikro, Kecil dan Menengah, (4) Pelibatan dalam pameran perdagangan untuk memperluas akses pasar, (5) Fasilitasi HAKI.. 4 dari 5 upaya sudah dilakukan dengan hasil yang masih perlu ditingkatkan, Adanya hambatan dan dukungan yang perlu menjadi perhatian bagi pemerintah daerah untuk meningkatkan keberdayaan UKMN.
\end{abstract}

Kata Kunci: Pemberdayaan, UMKM, Kampung Batik Jetis, INTAKO Tanggulangin

\begin{abstract}
Sidoarjo is a SMEs city that has a number of industrial quite a lot, one of which is a small industry of batik artisans that located in Kampung Batik Jetis and Intako Cooperative Craftsmen in Tanggulangin, Sidoarjo. How is the empowerment program that supports the development of batik craftsmen and intako craftsmen in Sidoarjo? And what are the factors inhibiting and supporting batik craftsmen and intako craftsmen?; Empowerment to those carried out by the Department of Cooperatives, SMEs, Industry, Trade, and Energy and Mineral Resources Sidoarjo conducted with various efforts, namely (1) facilitation of capital, (2) support the ease of obtaining raw materials and support facilities in the production process, (3) education and training to improve managerial capability and production, and other types of education and training that can support the empowerment of Micro, Small and Medium Enterprises, (4) involvement in trade fairs to expand market access, (5) facilitation of IPR. Four of five attempts have been made and the results still needs to be improved. The existence of barriers and support needs to be a concern for local governments to increase the empowerment of MSME
\end{abstract}

Keywords: Empowerment, MSME, Kampung Batik Jetis, INTAKO Tanggulangin.

\section{PENDAHULUAN}

Kemiskinan merupakan masalah dalam pembangunan yang bersifat multidimensi, yang berkaitan dengan aspek sosial, ekonomi, budaya, dan aspek lainnya. Kemiskinan ditandai oleh keterisolasian, keterbelakangan, dan pengangguran yang kemudian meningkat menjadi antardaerah, antarsektor, dan antar golongan penduduk (Sumodiningrat, 1998: 26). Salah satu sektor yang berperandalam menangani masalah kemiskinan adalah sector Usaha Mikro Kecil dan Menengah (UMKM). UMKM mampu memberi kesempatan kerja pada jutaan penduduk di Indonesia yang tidak tertampung di sektor formal atau sector usaha besar. Karakteristik UMKM juga sesuai dengan karakteristik penduduk miskin yang berpendidikan rendah.Potensi sumber daya yang besar yang dimiliki oleh Indonesia salah satunya adalah potensi sumber daya ekonomi.Kondisi perekonomian di Indonesia salah satunya ditopang oleh perekonomian Usaha Kecil Menengah (UKM). Menurut Gubernur Bank Indonesia Agus Martowardojo yang dikutip dari situs www.kabarbisnis.com bahwa UKM ini memberikan kontribusi hingga 99\% bagi perkembangan ekonomi Indonesia yang pada tahun lalu mencapai 6,2\% dan sisanya $1 \%$ dalam bentuk usaha besar. UKM merupakan 
satu sektor yang mampu bertahan dalam situasi ekonomi global yang sedang tertekan.

Kabupaten Sidoarjo merupakan kota UKM yang terbanyak di Indonesia. Salah satu industri kecil yang khas dari Sidoarjo yaitu Batik Tulis Sidoarjo dan Sentra Industri Tas dan Koper Tanggulangin Sidoarjo (INTAKO) merupakan salah satu sentra tas terbesar di Indonesia. Pembangunan merupakan suatu usaha atau proses perbaikan yang tiada akhir untuk berubah menjadi lebih baik lagi dan demi tercapainya tingkat kesejahteraan atau mutu hidup masyarakat. Menurut Slamet yang dikutip dalam Mardikanto dan Soebiato (2012:.6) untuk tercapainya tujuan-tujuan pembangunan, maka kegiatan pembangunan memerlukan "teknologiteknologi” tertentu. Pengertian teknologi tersebut adalah kebijakan dan peraturan-peraturan yang dikeluarkan baik oleh pemerintah pusat sampai dengan petunjuk teknis dan petunjuk pelaksanaan yang dikeluarkan instansi yang terendah.

Undang-Undang nomer 20 tahun 2008 tentangusaha mikro, kecil dan menengah dan diturunkan kembali dengan Peraturan Daerah Provinsi Jawa Timur nomer 6 tahun 2011 tentang pemberdayaan usaha mikro, kecil dan menengah. Dalam Perda tersebut disebutkan bahwa pemberdayaan terhadap UMKM dapat dilakukan dalam bentuk: fasilitasi permodalan, dukungan kemudahan memperoleh bahan baku dan fasilitas pendukung dalam proses produksi, pendidikan dan pelatihan untuk meningkatkan kemampuan manajerial dan produksi serta lain-lain, pelibatan dalam proses pengadaan barang dan jasa yang dilakukan instansi pemerintah, dan fasilitasi HAKI.

Batik merupakan warisan budaya Indonesia yang harus dilestarikan.Menurut Musman dan Arini (2011:1) bahwa batik Indonesia merupakan suatu keseluruhan teknik, teknologi serta pengembangan motif dan budaya yang terkait, yang oleh UNESCO ditetapkan sebagai warisan Kemanusiaan untuk Budaya Lisan dan NonBendawi sejak Oktober 2009.Pada tanggal 3 Mei 2008 Bupati Sidoarjo meresmikan Jetis sebagai daerah industri batik dan diberi nama "Kampoeng Batik Jetis". Industri kecil batik di Kampoeng batik Jetis pada tahun 2007 mengalami penurunan produksi yang mengakibatkan pengrajin hampir gulung tikar dalam usahanya.Hal tersebut karena sumber daya manusia dari pengrajin batik di Kampoeng Batik Jetis sangat rendah sehingga berdampak pada usaha yang dijalani.Seperti yang diungkapkan oleh Wulandari (2011:67) bahwa tantangan besar yang dihadapi oleh industri batik di Indonesia adalah sumber daya manusia.

Sedangkan UMKM yang berada di Tanggulangin Sidoarjo adalah Sentra Industri Tas dan Koper Tanggulangin Sidoarjo merupakan salah satu sentra tas terbesar di Indonesia. Di sentra tersebut, terdapat sebuah koperasi yang bernama Koperasi INTAKO yang berfungsi memberikan berbagai program kegiatan sebagai bentuk pemberdayaan pada UMKM sehingga dapat menghilangkan ketidakberdayaan pada anggotanya dan dapat mewujudkan kemandirian ekonomi masyarakat di kawasan sentra tersebut.

Ketidakberdayaan UMKM terlihat saat mereka diserang oleh produk- produk impor yang masuk dengan harga yang sangat bersaing. Sebagai akibat yang dirasakan oleh UMKM adalah omset menurun terutama bagi pelaku usaha mikro yang sangat rentan dengan kondisi kemiskinan. Koperasi INTAKO sebagai salah satu bentuk kelembagaan yang dipilih memiliki tujuan yaitu mensejahterakan seluruh anggota dengan asas gotong royong serta kekeluargaan.

Bagaimana Program pemberdayaan yang mendukung pengembangan UMKM pengrajin batik dan pengrajin Intako di kota Sidoarjo? Dan apa saja yang menjadi factor penghambat dan pendukung di dalam UMKM Pengrajin Batik dan UMKM Intako?

\section{METODE}

Penelitian ini menggunakan pendekatan kualitatif yaitu dalam upaya mendiskripsikan dan menganalisi bagaimana peran Pemerintah dalam mendukung pemberdayaan UMKM Batik dan UKM Intako berdasarkan peraturan daerah nomer 6 tahun 2011 ( Studi di Dinas Koperasi, UKM, Perindustrian, Perdagangan dan ESDM Kabupaten Sidoarjo dan Industri Kecil Kampoeng Batik Jetis Kabupaten Sidoarjo dan Pemberdayaan Koperasi Intako pada umkm disentra industri tas dan koper Tanggulangin Sidoarjo dalam upaya pencegahan kemiskinan.

Jenis penelitian ini dikategorikan sebagai penelitian deskriptif. Penelitian deskriptif adalah penelitian yang mempelajari masalah - masalah dalam masyarakat serta tata cara yang berlaku dalam masyarakat serta situasi - situasi termasuk tentang hubungan, kegiatan, sikap, pandangan serta proses yang sedang berlangsung dan pengaruh dari suatu fenomena. Pada penelitian ini mengembangkan konsep dan menghimpun fakta tetapi tidak melakukan pengujian hipotesis (Hasan, 2006).

Analisis data menggunakan metode analisis model interaktif yang menurut Miles dan Huberman yang dikutip Sugiyono (2013:91) ada tahapan yang harus dilalui yakni: reduksi data, penyajian data, dan menarik kesimpulan.

\section{HASIL DAN PEMBAHASAN}

Sidoarjo yang merupakan kota UKM memiliki jumlah industri kecil yang dapat menjadi kegiatan 
ekonomi masyarakat Sidoarjo. Dari banyaknya jumlah industri kecil di Sidoarjo yang merupakan produk unggulan daerah salah satunya adalah industri kecil batik jetis Sidoarjo dan pengrajin intako (industry tas dan koper) di Tanggulangin Sidoarjo.

Pemberdayaan Pemerintah Daerah Kabupaten Sidoarjo melalui Dinas Koperasi, UKM, Perindustrian, Perdagangan dan ESDM (Diskoperindag). Diskoperindag dan ESDM Kabupaten Sidoarjo dengan melakukan pembinaan melaluhi (1) Fasilitasi permodalan, (2) Dukungan kemudahan memperoleh bahan baku dan fasilitas pendukung dalam proses produksi, (3) Pendidikan dan pelatihan untuk meningkatkan kemampuan manajerial dan produksi serta lain-lain jenis pendidikan dan pelatihan yang dapat mendukung pemberdayaan Usaha Mikro, Kecil dan Menengah, (4) Pelibatan dalam pameran perdagangan untuk memperluas akses pasar, (5) Fasilitasi HAKI.

1) Fasilitasi permodalan,

Fasilitas permodalan diberikan pemerintah daerah dengan memberikan kesempatan pengajuan kredit dengan bunga rendah, hal ini telah di informasikan baik kepada Pengrajin Batik Jetis dan di INTAKO. UMKM Intako (Industri Tas dan Koper) Tanggulangin Sidoarjo telah di fasilitasi oleh pemerintah untuk permodalan dengan adanya KUR dengan bunga $6 \%$ pertahun. Anggota di Koperasi INTAKO terdiri dari berbagai skala usaha, yaitu usaha mikro, usaha kecil, dan usaha menengah. Usaha Mikro Kecil dan Menengah (UMKM) dibagi menjadi 2 (dua) kategori.UMKM yang bergerak di sektor industry pengelolahan, kaidah pendefinisiannya mengikuti definisi BPS berdasarkan jumlah tenaga kerja. Sedangkan yang non industri, pendefinisiannya mengikuti Undang-undang No.20 Tahun 2008 tentang UMKM. Untuk industry pengolahan, pengelompokannya sebagai berikut: (1) Industri yang termasuk usaha mikro adalah industri/usaha kerajinan rumah tangga yang mempunyai pekerja antara 1 - 4 orang; (2) Industri yang termasuk usaha kecil adalah industri yang mempunyai pekerja 5 - 19 orang; (3) Industri yang termasuk usaha menengah adalah industri yang mempunyai pekerja 20 99 orang. Program fasilitas adanya pinjaman modal ternyata memang lebih menonjol dilaksanakan di INTAKO. Program ini pemberian fasilitas permodalan di lakukan oleh Diskoperindag dan ESDM Kabupaten Sidoarjo bekerja sama dengan Bank Jatim. Upaya ini telah dilakukan dan berjalan tetapi masih sebagian dari Pengrajin Batik Jetis dan di INTAKO. UMKM Intako (Industri Tas dan Koper) Tanggulangin Sidoarjo yang dapat memanfaatkan.

Bahkan sebagai upaya dari pelaku UMKM sendiri adalah dengan adanya koperasi UMKM Intako ini bermodalkan dari hasil simpanan pokok. Setiap anggota wajib menabung tiap bulan Rp. 5000 sehingga terkumpul simpanan pokok Rp.135.000,00. 50\% dari simpanan pokok anggota akan dipinjamkan kepada anggota koperasi sebagai bagian dari upaya peningkatkan modal usaha. Koperasi INTAKO merupakan wadah pemersatu yang dipilih oleh para pengrajin di sentra industri tas dan koper di Tanggulangin untuk memudahkan mereka menjalankan aktivitas bisnisnya sehingga tercipta UMKM yang mandiri.

2) Dukungan kemudahan memperoleh bahan baku dan fasilitas pendukung dalam proses produksi.

Program pemberdayaan yang dilakukan oleh Diskoperindag dan ESDM Kabupaten Sidoarjo adalah dengan pembinaan peningkatan kemampuan teknologi. Pembinaan peningkatan kemampuan teknologi yang berupa kemampuan teknologi dalam produksi batik dan kemampuan teknologi dalam pemasaran. Upaya ini tentu diharapakn agar dapat meningkatkan kemandirian pengrajin batik dalam mengembangkan usahanya. Namun hasil dari pelatihan tersebut belum optimal karena kurangnya kesadaran pengrajin batik untuk mengikuti pelatihan.

Di INTAKO, Tanggulangin kemudahan utuk mendapatkan bahan baku telah diupayakan juga melaluhi koperasi sedangkan koperasi tersebut juga dalam binaan dinas. Sehingga ada sinergi antara upaya pemberdayaan pemerintah kota dan upaya UMKM dalam meningkatkan kemandirian usahanya.

3) Pendidikan dan pelatihan untuk meningkatkan kemampuan manajerial dan produksi serta lain-lain jenis pendidikan dan pelatihan yang dapat mendukung pemberdayaan Usaha Mikro, Kecil dan Menengah.

Pendididkan dan pelatihan juga telah dilakukan untuk meningkatkan kemampuan pengrajin batik dan juga di INTAKO. Melalui Diskoperindag dan ESDM Kabupaten Sidoarjo melakukan suatu pembinaan dan pemberdayaan untuk mengatasi permasalahan yang dialami oleh industri kecil batik di Kampoeng Batik Jetis. Pengembangan sumber daya manusia yang dilakukan yaitu berupa pelatihan desain dari batik maupun tas dan koper hal ini dilakukan agar model atau motif batik maupun tas dan koper dapat sesuai dengan mode saat ini.

Pelatihan dan motivasi kewirausahaan juga dilakukan dalam rangka menigkatkan keahlian dalam pengelolaan usaha. Program pelatihan dan pemberian motivasi ini masih belum dapat dirasakan secara menyeluruh oleh pengrajin batik di Kampoeng Batik Jetis. Dan pengusaha INTAKO, sehingga perlu ada pelatihan dan pemberian motivasi terhadap pengelola UMKM. 
4) Pelibatan dalam pameran perdagangan untuk memperluas akses pasar,

Program ini diberikan pada Pengrajin Batik Kampoeng Jetis dan INTAKO dengan memberikan fasilitas pemasaran.. Program ini dilakukan dengan cara Diskoperindag dan ESDM dengan memberikan fasilitas pemasaran. Diskoperindag dan ESDM mengundang UMKM untuk mengikuti pameran, promosi dan misi dagang yang dilakukan oleh dinas secara rutin. Program ini sudah berjalan dengan baik dan hasilnya cukup memuaskan bagi Pengrajin Batik Kampoeng Jetis dan Pengrajin INTAKO, Tanggulangin .

Pameran untuk membantu pemasaran produk UMKM, maupun fasilitasi legalitas. Akan tetapi, fasilitas-fasilitas tersebut belum dapat dinikmati oleh pelaku usaha mikro karena kondisi usaha belum memenuhi persyaratan kualitas atau mutu yang disyaratkan.

5) Fasilitasi HAKI.

Program ini ternyata belum begitu banyak diperkenalkan dan di lakukan Diskoperindag dan ESDM. Hal ini tentu arus menjadi program lanjutan agar kekayaan hak cipta untuk model atau disain yang khas di miliki oleh pengkrajin batik atau produk INTAKO mendapat perlindungan hak ciptanya.

Faktor Pendukung dan Penghambat Pemberdayaan Pengrajin Batik di Kampoeng Batik Jetis Kabupaten Sidoarjo dan Pengrajin Koperasi Intako di Tanggulangin

Faktor pendukung dalam program pemberdayaan di Pengrajin Batik Kampoeng Jetis ada 2 yaitu Faktor pendukung internal pemberdayaan yang dilakukan Diskoperindag dan ESDM antara lain: (1) Adanya akses teknologi yang membantu pegawai Diskoperindag dan ESDM untuk melakukan peninjauan perkembangan industri pengrajin batik. (2) Adanya kerja sama antara pemerintah dengan BUMN yang menjadikan Diskoperindag dan ESDM lebih mudah untuk melaksanakan pembinaan dan pemberdayaan. Faktor pendukung Eksternal, antara lain: (1) Produk batik yang sudah dikenal masyarakat. (2) Adanya dukungan dari pemerintah Kabupaten Sidoarjo.

Faktor penghambat Internal pemberdayaan yang dilakukan Diskoperindag dan ESDM terbatasnya dana yang menjadikan kurang optimalnya pemberdayaan pengrajin batik. Faktor penghambat eksternal yaitu: (1) Kurangnya kesadaran pengrajin batik untuk mengikuti pelatihan yang diberikan Diskoperindag dan ESDM Kabupaten Sidoarjo dan (2) Minimnya tenaga kerja pada industri kecil batik.

Faktor Penghambat Pemberdayaan Pengrajin Koperasi Intako di Tanggulangin Sidoarjo yaitu (1) adanya kebijakan makro dari Pemerintah yang tidak berpihak pada UMKM misalnya diberlakukannya kebijakan AFTA di Indonesia mengakibatkan omset INTAKO mengalami penurunan mulai Tahun 2004, (2) adanya bencana lumpur lapindo di Tahun 2006, (3) adanya persaingan produk -produk sejenis terutama di kawasan sentra industri tas dan koper Tanggulangin terutama para pengusaha besar yang memiliki showroom, (4) keterbatasan SDM meliputi keahlian atau tingkat pendidikan pekerja dan keahlian pengelola koperasi yang diperoleh secara otodidak secara turun temurun dari orang tua/ saudara mereka.

Sedangkan untuk faktor pendorong, (1) wadah kelembagaan yang dipilih oleh UMKM di sentra industri tas dan koper Tanggulangin adalah koperasi yang memberikan hak dan kewajiban yang sama kepada setiap anggotanya baik itu anggota dengan skala mikro, kecil maupun menengah sehingga suasana atau iklim yang ada di Koperasi INTAKO akan memungkinkan anggotanya dapat berkembang secara optimal, (2) pendirian Koperasi INTAKO sudah menerapkan fase emansipatif sehingga memberikan keterikatan emosi antar subyek pembangunan, (3) aturan, visi, dan misi Koperasi INTAKO dibuat atas dasar kesepakatan anggota pada waktu RAT, (4) sistem penerimaan produk barang jadi sudah memperhatikan skala usaha anggota yaitu dengan adanya sistem kuota dan konsinyasi yang memberikan keleluasaan bagi anggota untuk memilih sistem pemasaran produk yang cocok bagi kondisi usahanya

\section{PENUTUP}

\section{Simpulan}

Program Pemberdayaan di Pengrajin Batik Kampung Jetis Sidoarjo adalah Upaya pemerintah Kabupaten Sidoarjo untuk mendukung pertumbuhan industri kecil terutama pengrajin batik Kampoeng Batik Jetis. Pemberdayaan yang dilakukan oleh Diskoperindag dan ESDM Kabupaten Sidoarjo sudah memberikan manfaat dan dampak yang baik bagi pengrajin batik. Akan tetapi, dampak baik tersebut belum merata dirasakan oleh seluruh pengrajin batik dikarenakan program pemberdayaan belum menyeluruh dilakukan kepada semua pengrajin batik di Kampoeng Batik Jetis.

Sedangkan yang terjadi di Pengrajin Koperasi Intako Tanggulangin Sidoarjo adalah Pemberdayaan yangditemukan di Koperasi INTAKO pada UMKM di sentra industri tas dan koper Tanggulangin Sidoarjo sudah menggunakan prinsip partisipatoris dan berbasis pada people centereddevelopment. Akan tetapi program pemberdayaan yang dijalankan masih belum maksimal terutama dalam hal pemasaran, dan manajemen. 


\section{DAFTAR PUSTAKA}

Mardikanto, Totok dan Poerwoko, Soebiato.(2012). Pemberdayaan Masyarakat dalam Perspektif Kebijakan Publik. Bandung: Alfabeta.

Marto, Agus. (2013). Perekonomian RI ditopang oleh Sektor UMKM.Diakses melalui http://kabarbisnis.com/read/2841689.Diakses pada 15 September 2013.

Musman, Asti dan Ambar, Arini. (2011). Batik: Warisan Adiluhung Nusantara. Yogyakarta: G-Media.

Peraturan Presiden Nomor 32 Tahun 1998 Tentang Pembinaan dan Pengembangan Usaha Kecil, Jakarta, Kementrian Koperasi dan Usaha Kecil dan Menengah Republik Indonesia.

Peraturan Daerah Provinsi Jawa Timur Nomor 6 Tahun 2011 Tentang Pemberdayaan Usaha Mikro, Kecil dan Menengah(c.14), Surabaya, Pusat Jaringan Dokumentasi dan Informasi Hukum Provinsi Jawa Timur.
Subandi. 2010. Kedudukan danKiprah Koperasi dalam MendukungPemberdayaanUMKMwww.smecda.com/.. ./ jurna l/_9_\%20 Jurna l pemberda... diakses pada tanggal 22 November 2014

Suharto, Edi. 2010. Membangun Masyarakat dan Memberdayakan Masyarakat.Refika Aditama. Bandung.

Sumodiningrat, Gunawan. 1998.Membangun Perekonomian Rakyat.IDEA.Yogyakarta.

Suyanto, Bagong dan Karnaji. 2012. Kemiskinan dan Kesenjangan Sosial: Ketika Pembangunan Tak Berpihak Kepada Rakyat Miskin. Airlangga University Press.Surabaya.

Tambunan, Tulus T. H. 2009.UMKM DI INDONESIA. Ghalia Indonesia. Bogor. 